\title{
The unknown followers: Discovery of a new species of Sycobia Walker (Hymenoptera: Epichrysomallinae) associated with Ficus benjamina L. (Moraceae) in the Neotropical region
}

\author{
Fernando Henrique Antoniolli Farache', Cecilia Bernardo Pereira², \\ Cristiana Koschnitzke², Levi Oliveira Barros', Elmecelli Moraes de Castro Souza', \\ Daniel Tirapeli Felício ${ }^{3}$, Fabián Gatti ${ }^{4}$, William Cardona ${ }^{5}$, Jean-Yves Rasplus ${ }^{6}$, \\ Rodrigo Augusto Santinelo Pereira'
}

I Departamento de Biologia, FFCLRP - USP, 14040-901, Bairro Monte Alegre, Ribeirão Preto, SP, Brazil 2 Departamento de Botânica, Museu Nacional - UFRJ, 20940-040, São Cristovão, Rio de Janeiro, RJ, Brazil 3 Departamento de Ciências Biológicas, Faculdade de Ciências, UNESP, 17033-360, Vargem Limpa, Bauru, SP, Brazil 4 Centro de Pesquisa Ecológica Subtropical, DRNEA-Administração e Parques Nacionais, Av. Victoria Aguirre 66, Pto Iguazú, Misiones, Argentina 5 Departamento de Biología, Universidad del Valle, Calle 13 No. 100 - 00, Cali, Colombia 6 INRA, UMR 1062 CBGP, Centre de Biologie pour la Gestion des Populations, Montferrier-sur-Lez, France

Corresponding author: Fernando Farache (farache@usp.br)

Academic editor: P. Jansta | Received 14 September 2018 | Accepted 27 November 2018 | Published 31 December 2018

http://zoobank.org/320FF83E-A982-4A5B-8523-BEAD93993EE5

Citation: Farache FHA, Pereira CB, Koschnitzke C, Barros LO, Souza EMC, Felício DT, Gatti F, Cardona W, Rasplus J-Y, Pereira RAS (2018) The unknown followers: Discovery of a new species of Sycobia Walker (Hymenoptera: Epichrysomallinae) associated with Ficus benjamina L. (Moraceae) in the Neotropical region. Journal of Hymenoptera Research 67: 85-102. https://doi.org/10.3897/jhr.67.29733

\begin{abstract}
Biotic invasion in mutualistic communities is of particular interest due to the possible establishment of new relationships with native species. Ficus species are widely cultivated as ornamental plants, and they host specific communities of chalcid wasps that are strictly associated with the fig inflorescences. Some introduced fig species are capable of establishing new relationships with the local fig wasps, and fig wasp species may also be concomitantly introduced with their host plants. Ficus benjamina L. is widely cultivated across the world, but the associated fig wasps are not reported outside of the species native range. We describe for the first time a non-pollinating fig wasp associated with $F$. benjamina inflorescences outside its native distribution. Sycobia hodites Farache \& Rasplus, sp. n. is the third known species of the genus and was recorded in populations of F. benjamina introduced in the Neotropical region throughout several
\end{abstract}

Copyright F.H.A. Farache et al. This is an open access article distributed under the terms of the Creative Commons Attribution License (CC BY 4.0), which permits unrestricted use, distribution, and reproduction in any medium, provided the original author and source are credited. 
localities in Argentina, Brazil and Colombia. Sycobia is a gall-inducing non-pollinating fig wasp genus associated with fig trees in the Oriental and Australasian regions. This species competes with pollinators for oviposition sites and may hinder the future establishment of the native pollinator of $F$. benjamina, Eupristina koningsbergeri Grandi, 1916 in the New World. However, the occurrence of a gall inducing species in this host plant may open ecological opportunities for the establishment of species belonging to other trophic levels such as cleptoparasite and parasitoid wasps.

\section{Keywords}

biocontrol, Chalcidoidea, dispersal, invasive species, parasitoid

\section{Introduction}

Biotic invasions are altering the world's natural communities at an unprecedented level, and they impose a global challenge for the conservation of biodiversity and the maintenance of ecological communities (Mack et al. 2000; Simberloff et al. 2013; Vitousek et al. 1997). The role of biological invasions in symbiotic communities is of particular interest, since introduced plants and phytophagous organisms may establish new relationships with native species and change the community structure. Generalism and specialism have a central role in the capacity of establishment in invasive species. In the case of plants, groups with specialized pollination syndromes are less likely to reproduce in foreign environments than generalist species that are pollinated by widely distributed species (Richardson et al. 2000).

Ficus establishes mutualistic relationships with pollinating agaonid wasps that develop in their inflorescences. These wasps induce galls in fig inflorescences. Several other lineages of chalcid wasps utilize fig inflorescences as oviposition sites without pollinating (but see Jousselin et al. 2001), and they may induce galls or develop as inquilines or parasitoids, sometimes hyperparasitoids, of other galling wasps (Kjellberg et al. 2005). Several fig species are widely used as ornamental plants, as examples we can cite F. benjamina L., F. benghalensis L., F. lyrata Roxb., F. macrophylla Desf. ex Pers., F. microcarpa L. f., F. pumila L., F. religiosa L., and F. rubiginosa Desf. ex Vent. (Dehgan 1998; Ibarra-Manríquez et al. 2012). These trees are cultivated in urban areas and roadsides in several (sub)tropical but also temperate countries. As they depend on their specific pollinators to reproduce, they cannot propagate sexually outside their original range of distribution in the absence of their obligate pollinators. Nevertheless, the pollinators of some Ficus species have been accidentally or deliberatively introduced in several regions of the globe (Beardsley 1998; Ramírez and Montero 1988; Vianna-Filho et al. 2017) and some of these fig species may become invasive. In a few cases, wasp species associated with local figs may colonize the newly introduced fig trees, develop inside figs and pollinate (Ramírez and Montero 1988; van Noort et al. 2013). Non-pollinating fig wasps also often establish outside their native ranges on their native host-plant. These species are usually referred as 'followers' whereas some local species that colonize introduced fig species are referred as 'colonists' (van Noort et al. 2013; Wang et al. 2015a).

Within the Neotropical region several species of pollinating and non-pollinating fig wasps are associated with the oriental F. microcarpa (Farache et al. 2009; Figueiredo 
and Motta-Júnior 1986; Figueiredo and Motta-Júnior 1993; Figueiredo et al. 1995; Ramírez and Montero 1988). To the contrary, only the pollinator (i.e., Platyscapa quadraticeps Mayr, 1885) of F. religiosa has been observed (Vianna-Filho et al. 2017). Until now, there was no register of Old-World fig wasps associated with F. benjamina, another widely ornamental cultivated species, in the Neotropical region. Indeed, there is no report of Old-World fig wasps associated with F. benjamina outside its native range. However, a native Neotropical fig wasp species has been recorded developing in F. benjamina figs in Costa Rica (Ramírez and Montero 1988).

Epichrysomallinae are distributed throughout the Old-World tropics and the group is particularly diverse in the Oriental region (Bouček 1988; Rasplus et al. 2003). They are naturally absent from the Neotropical region except for species of Odontofroggatia Ishii, 1934 introduced with their host plant (F. microcarpa) (Farache et al. 2009; Rasplus and Soldati 2005; Wang et al. 2015a). They induce large galls inside the figs either in the flowers or in the fig wall. A few species are known to induce galls on fig leaves (Beardsley and Rasplus 2001) or on fig twigs (Ferrière 1929). Their ovipositor does not protrude beyond the metasoma as in many non-pollinating fig wasps, but is coiled inside the metasoma (Galil and Copland 1981). Epichrysomallinae exhibit several degrees of sexual dimorphism. Possibly due to their small brood size, most species have only winged males. Brachypterous and apterous males are only known in three genera, namely Neosycophila Grandi, 1923, Lachaisea Rasplus, 2003 and Camarothorax Mayr, 1906 (Bouček 1988; Joseph 1961; Vincent and Compton 1992)(Bouček 1988; Joseph 1961; Vincent and Compton 1992)(Bouček 1988; Joseph 1961; Vincent and Compton 1992) .

About 49 species names are associated with 19 genera of Epichrysomallinae (van Noort and Rasplus 2018), but the circumscription of the genera is still unclear, and the subfamily requires a thorough taxonomic revision. Among the Epichrysomallinae genera, Sycobia Walker, 1871 is closely related to Odontofroggatia (Feng and Huang 2010). Both genera are characterized by the absence of external occipital carina; notauli reaching the transscutal articulation outside of scutoscutellar sutures; absence of submarginal vein; and presence of only 5 or 6 funicular segments. Sycobia can be separated from Odontofroggatia by its pentamerous tarsi (tetramerous in Odontofroggatia, the species cited as pentamerous by Bouček (1988) is probably a misidentification of a female Sycobia); antennal formula 11163, with presence of an anellus, sometimes subquadrate (11063 or 11053 in Odontofroggatia, no anellus); the shape of the male head, which is elongated or subquadrate (subcircular in Odontofroggatia). Two species of Sycobia are described from India, namely S. bethyloides Walker, 1871 and S. mathewi Joseph, 1956 (Joseph 1956). At least one undescribed species is also cited to be associated with F. benjamina in China (Niu et al. 2009) and many undescribed species are known from South-East Asia (Rasplus J.-Y. pers. comm.).

Here we report the first occurrence of Sycobia outside its native range. The species discovered is new to science and is probably associated with $F$. benjamina (section Conosycea) somewhere in its large native distribution, which extends from India to Australia. Sycobia hodites Farache \& Rasplus, sp. n. is described and characters to distinguish it from congeneric wasps are given. The distribution of this new species over the Americas and its abundance in fig syconia is also reported on. 


\section{Methods}

\section{Specimen sampling and localities analyzed}

After observing the presence of fig wasp galls in Ficus benjamina in Rio de Janeiro/ Brazil, fig samples were collected between August 2016 to August 2018 in several localities in Argentina (Misiones), Brazil (states of Acre, Bahia, Distrito Federal, Pará, Rio de Janeiro, Rio Grande do Norte, Roraima, Santa Catarina and São Paulo) and Colombia (Valle del Cauca).

Near ripe figs were collected and left in netting bags until wasp emergence, after 2-3 days. Wasps were then killed with ethyl acetate and conserved in $70 \%$ ethanol. In each sampling site, 10-30 figs were dissected in order to quantify the number of Sycobia galls. As only one fig wasp specimen emerged from a gall, the number of galls may correspond to the number of wasps developing in the figs.

For one tree in Ribeirão Preto city/Brazil, figs were individualized in plastic specimen jars until the wasps emerged, then the number of wasps and total fig flowers were quantified in order to evaluate (1) the percentage of fig flowers occupied by wasps and (2) the sex ratio and the proportion of winged and wingless males observed in an individual fig.

Distribution maps for the occurrence of Sycobia hodites sp. n. and for samples of F. benjamina that did not show any wasp galls, as well as abundance exploratory data analyses were performed using R v3.4.2 (R Core Team 2018) and the packages ggplot2 (Wickham 2009), ggsn (Baquero 2017) and rnaturalearth (South 2017).

\section{Specimen preparation and description}

Wasp specimens were dried using a Critical Point Drier (BALTEC CPD 0300) and card-mounted following Noyes (1982). A few specimens were mounted on grey triangular cards in order to facilitate imaging. Acronyms for specimen depositories are as following:

CBGP Centre de Biologie pour la Gestion des Populations, Montferrier-surLez, France;

MUSENUV Universidad del Valle Museum - Museo de Entomología de la Universidad del Valle;

RPSP Universidade de São Paulo, Ribeirão Preto, Brazil.

Images of specimens were produced using a Keyence VHX-5000 digital microscope. Some specimens were dissected, mounted and sputter-coated with gold for scanning electron microscopy (SEM), which was performed with a JEOL JCM-6000Plus microscope. Images were then edited in Pixelmator v.3.7. Measurements were taken using ImageJ (Abràmoff et al. 2004). 


\section{Results}

\section{Sampling and bionomics}

Sycobia hodites Farache \& Rasplus, sp. n. was reared from figs in Argentina, South, Southeastern, North and Northeastern Brazil, and in Colombia, but was not observed in fig samples of F. benjamina from Acre and Roraima (Fig. 1), suggesting that Sycobia hodites may still be absent in central and western Amazon. Each gall of Sycobia was induced in a single fig pistillate flower, as remnants of flower stigmata could be observed on the galls (Fig. 2). The larva develops at the expense of the induced gall tissues.

Figs of $F$. benjamina were $1.12 \pm 0.07 \mathrm{~cm}$ long (measured from ostiole - peduncle insertion) $\times 0.99 \pm 0.05 \mathrm{~cm}$ wide (Mean $\pm S D, N=30$ figs) and shown an average of 359.5 flowers per fig (Table 1). The average number of Sycobia wasps per fig ranged from 5.07 (Brazil, PA) to 57 (Brazil, SP; Fig. 3). Sycobia wasps occupied an average of $18 \%$ of the available female flowers.

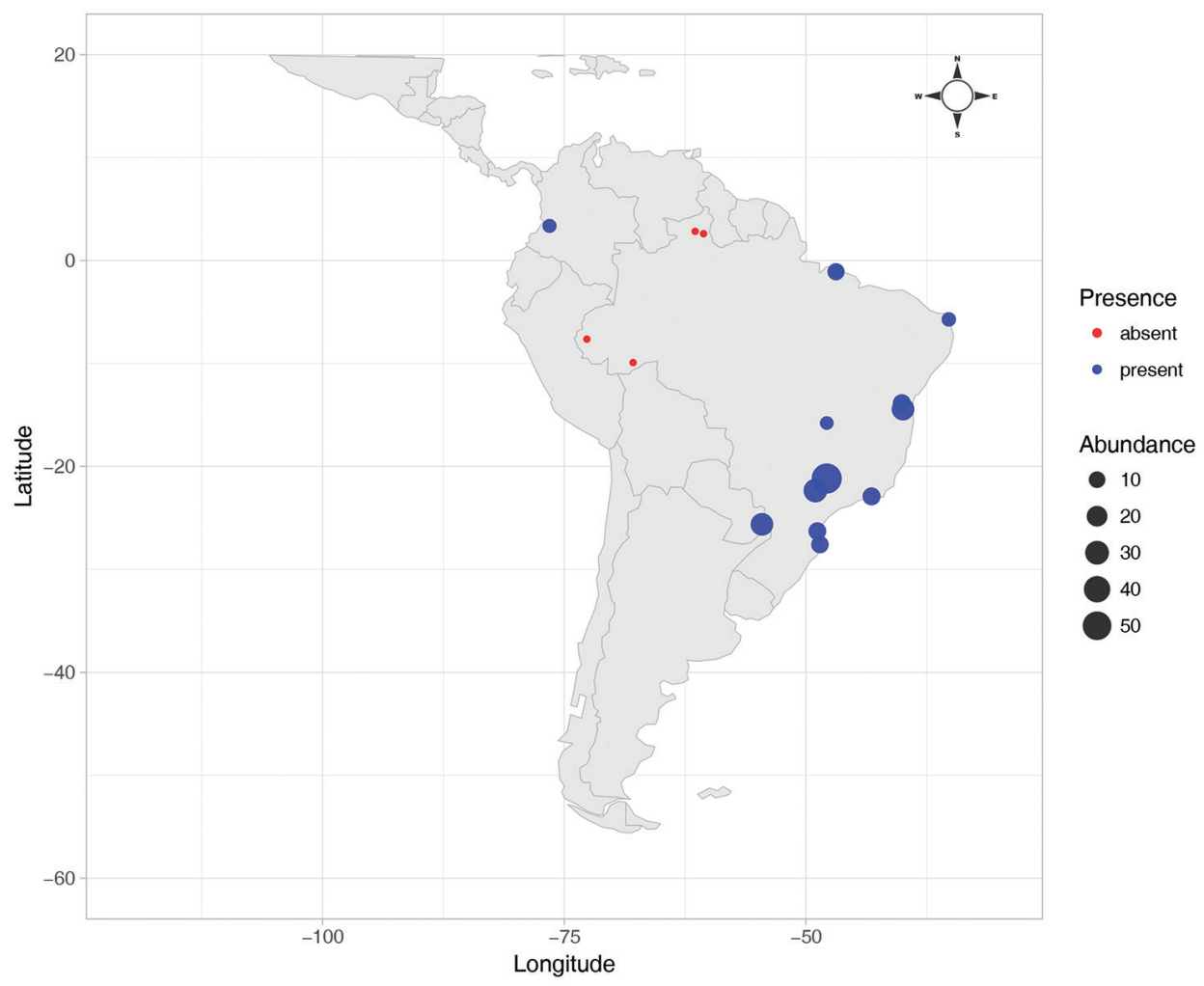

Figure I. Sycobia hodites Farache \& Rasplus, sp. n., Sampling. Blue circles represent abundances where the species was sampled, whereas red circles represents localities where $F$. benjamina was sampled but no evidence of galls were found. Made with natural earth (naturalearthdata.com). 

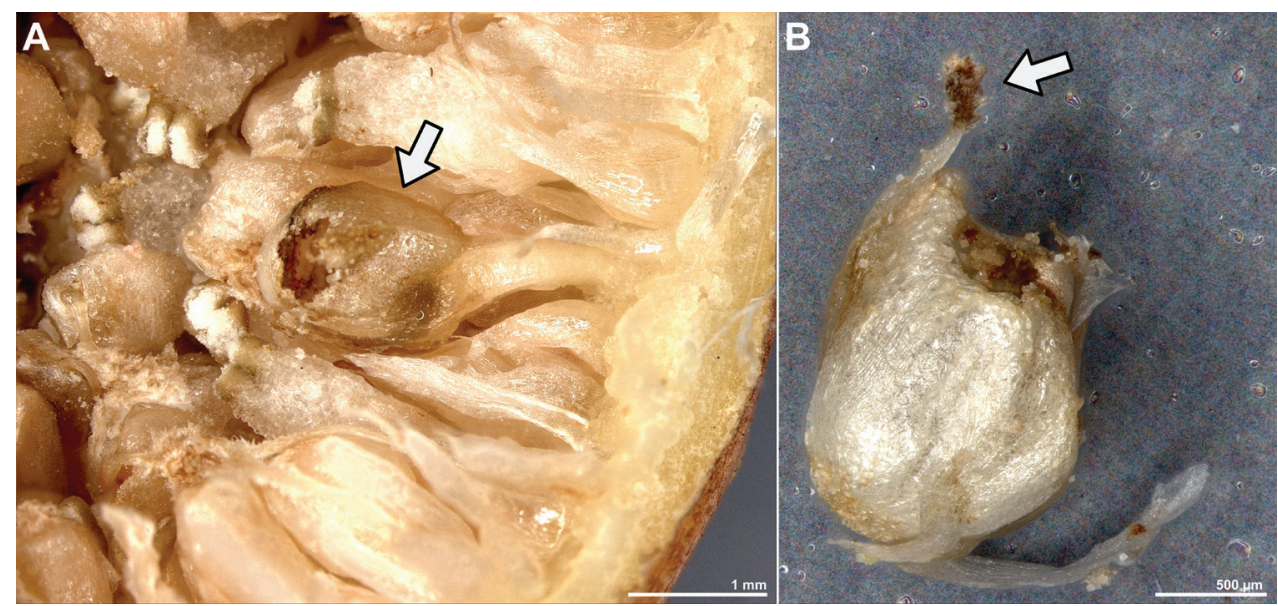

Figure 2. A Detail of galls induced by Sycobia hodites Farache \& Rasplus, sp. n. arrow indicates the gall. B Arrow indicates remains of flower stigma in the gall.

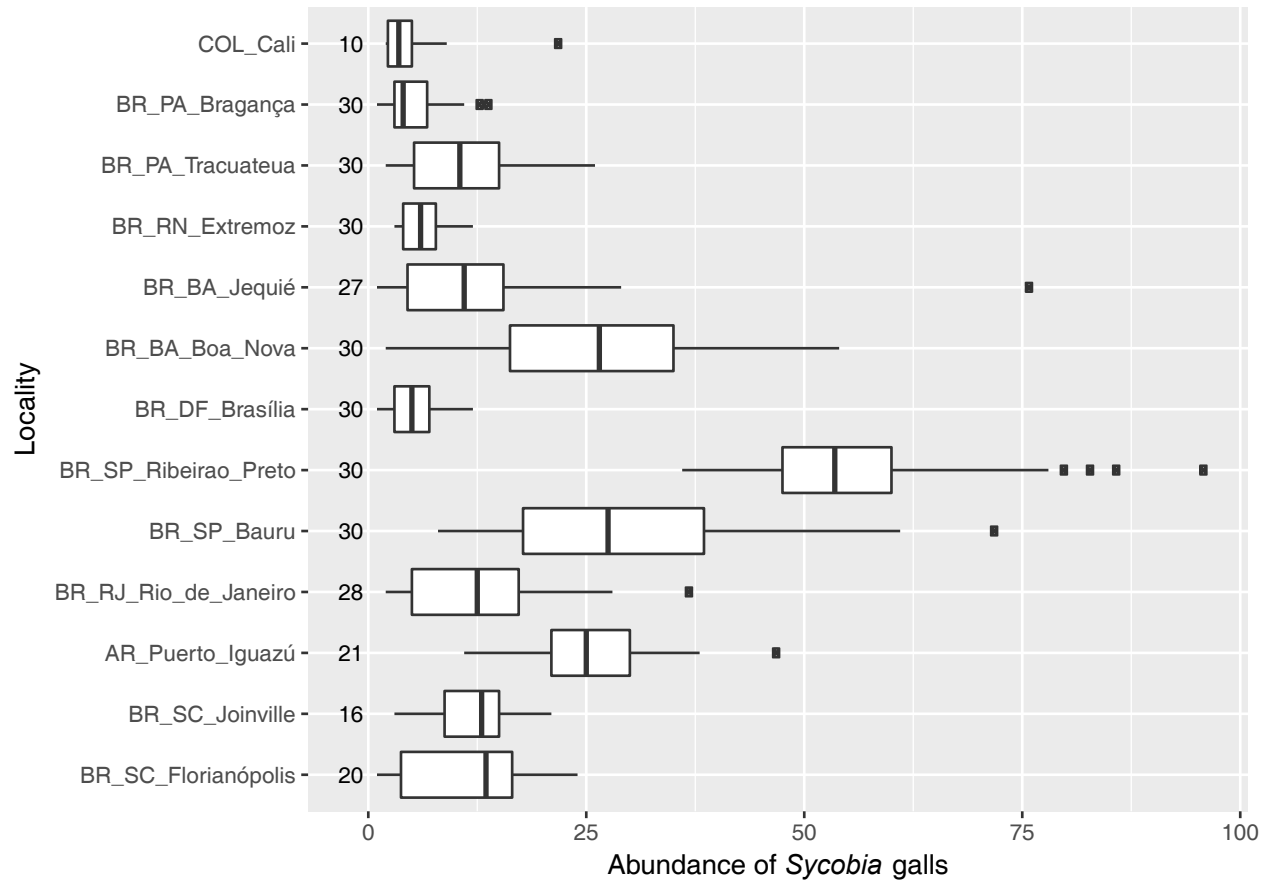

Figure 3. Average abundance of Sycobia hodites Farache \& Rasplus, sp. n. galls in Ficus benjamina. The number of galls was calculated when Sycobia was present in the figs. Localities sorted by latitude. Countries: $\mathrm{AR}=$ Argentina, $\mathrm{BR}=$ Brazil, $\mathrm{COL}=$ Colombia; Brazilian States: $\mathrm{BA}=$ Bahia, DF $=$ Distrito Federal, $\mathrm{PA}=$ Pará, $\mathrm{RJ}=$ Rio de Janeiro, $\mathrm{RN}$ = Rio Grande do Norte, $\mathrm{SC}=$ Santa Catarina, $\mathrm{SP}=$ São Paulo. Numbers on the left side of the plot indicate sample sizes. 
Table I. Number of flowers and wasps in figs sampled in Ribeirão Preto. $\mathrm{N}=$ number of figs, $\mathrm{m}=$ males, $\mathrm{f}=$ females, wm $=$ winged males.

\begin{tabular}{lcc}
\hline \multicolumn{1}{c}{ Character } & Mean $\pm \boldsymbol{S D}$ & $\mathbf{N}$ \\
\hline Pistillate flowers & $359.5 \pm 44.87$ & 10 \\
Staminate flowers & $44.3 \pm 8.37$ & 10 \\
Female wasps & $37.73 \pm 11.76$ & 30 \\
Winged males & $1.2 \pm 1.13$ & 20 \\
Brachypterous males & $18.07 \pm 6.02$ & 30 \\
Sex ratio $(\mathrm{m} /(\mathrm{m}+\mathrm{f}))$ & $0.34 \pm 0.08$ & 30 \\
Winged-male sex ratio $[\mathrm{wm} /(\mathrm{m}+\mathrm{f})]$ & $0.022 \pm 0.024$ & 30 \\
\hline
\end{tabular}

Most males were brachypterous. Winged males were comparatively less frequent. Sex ratio was female biased, with males representing only $34 \%$ of the total wasp offspring (Table 1). The winged males were commonly observed copulating with the females, even inside figs, whereas no mating was observed with brachypterous males.

\section{Systematic position and species description}

Family Pteromalidae Dalman, 1820

Subfamily Epichrysomallinae Hill \& Rieck, 1967

Sycobia Walker, 1871 [Type species: Sycobia bethyloides Walker, 1871]

\section{Sycobia hodites Farache \& Rasplus, sp. n.}

urn:lsid:zoobank.org:act:DB49C03E-1FB3-4B01-9AB1-293E6EA83152

Figs 4-7

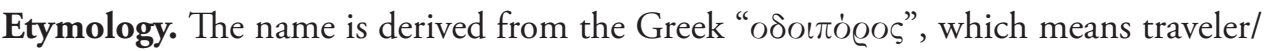
wayfarer.

Type material. Holotype: + BRAZIL, São Paulo, Ribeirão Preto, Jardim Recreio, -21.1754 $-47.8579^{\circ}$, 560m elev., 23.viii.2016 ex Ficus benjamina, no RASP00417, Pereira, RAS leg. USP_RPSP 00003485 (RPSP). Paratypes: BRAZIL, same informa-

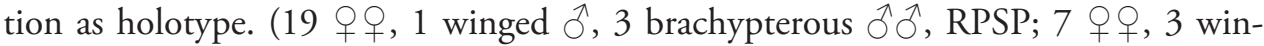

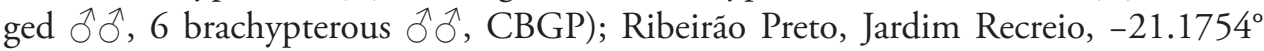
$-47.8579^{\circ}, 560 \mathrm{~m}$ elev. 29.v.2017, $\mathrm{n}^{\circ}$ RASP00434, Pereira, RAS leg. (12 $q$,+ 4 winged

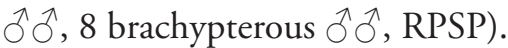

Non-type specimens. BRAZIL, Rio de Janeiro, Rio de Janeiro, Horto Botânico, Museu Nacional, $-22.9083^{\circ}-43.2247^{\circ}, 15 \mathrm{~m}$ elev., 23.vii.2016, ex Ficus benjamina,

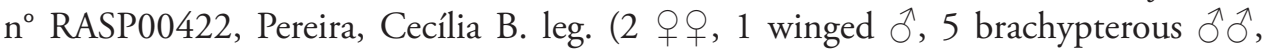
RPSP); Santa Catarina, Florianópolis, $-27.5901^{\circ}$-48.5619 ${ }^{\circ}, 15 \mathrm{~m}$ elev., 19.ii.2017, ex Ficus benjamina, $\mathrm{n}^{\circ}$ RASP00431, Koschnitzke, C leg. (3 brachypterous ${ }^{\lambda} \delta$, RPSP); 
COLOMBIA, Valle del Cauca, Cali, La Leonera, 3.4519 $-76.6558^{\circ}, 1930 \mathrm{~m}$ elev, 12.x.2016 ex Ficus benjamina, Cardona W. leg (29 우, 2 winged $\widehat{\jmath} \widehat{\jmath}, 39$ brachypterous $\widehat{\jmath} \hat{\jmath}$, MUSENUV).

Species description. Diagnosis: Female body color mostly yellow. Anellus transverse, very short (less than $0.2 \times$ the first flagellomere length). Clypeal margin sinuate, without distinct lobes. Propodeum with a median longitudinal crest reaching the posterior part of the sclerite and with two broad furrows, parallel to the anterior margin of propodeum. Male petiole short, inconspicuous.

Female (Figs 4, 5). Body (head + mesosoma + metasoma) length $2.1 \mathrm{~mm}$. Body color mostly yellow. Mandibles and oral margin darker, mostly brown. Mesosoma in dorsal view yellow to orange. Metasoma yellow to orange, dorsally brown to black.

Head. Transverse, 1.2-1.4x as wide as high. Face and vertex sculpture mostly engraved, with sparse pilosity. Scrobal depression shallow, smooth. Supraclypeal area mostly smooth. Clypeal margin sinuate, without distinct lobes. Clypeus with two pairs of setae. Distance between toruli ca $0.6 \times$ torulus diameter. Distance from torulus to oral margin $0.6 \times$ distance from torulus to median ocellus; antennae inserted above the level of the ventral margins of the compound eyes and below the median region of compound eyes. POL 1.8× OOL. Mandibles bidentate. Malar sulcus absent. Antennal formula 11163 . Scape $2.5 \times$ as long as pedicel. Anellus transverse, very short (less than $0.2 \times$ the first flagellomere length). Funicular segments transverse, $0.6-0.8 \times$ as long as wide, each of them bearing a single row of sensilla. First funicular segment with 6-7 longitudinal sensilla, the remaining funicular segments with 8-10 longitudinal sensilla in each. Claval segments fused, each one bearing a single row of sensilla

Mesosoma. Pronotum sculpture smooth to engraved. Prosternun transverse, nearly $1.5 \times$ as wide as long, with smooth to engraved sculpture. Mesoscutum sculpture smooth to engraved, median region transversally engraved, strigose. Notauli becoming faint near transscutal articulation. Axilla transverse in dorsal view; both axillae almost touching near the median region of transscutal articulation; sculpture smooth to engraved. Mesoscutellum sculpture mostly smooth, sculpture smoother than in mesoscutum and axillae. Mesoscutellum with 2 pairs of long setae, inserted in the sublateral and postero-lateral margin of the sclerite. Mesepisternum and mesepimeron fused, with engraved sculpture. Metascutellum inconspicuous. Propodeum with a median longitudinal crest reaching the posterior part of the sclerite. Anterior portion of propodeum with two broad furrows, parallel to the anterior margin of propodeum. Propodeum sculpture engraved to coriaceous ("scale-like"). Posterior region of propodeum with longitudinal striae. Propodeal spiracles $1 \times$ its diameter distant from propodeal anterior margin; anterolateral margin of propodeal spiracles covered by a rounded expansion of propodeal tergite. Wings hyaline, with sparse pilosity; wing margin moderately pilose. Marginal vein virtually as long as stigmal vein. Postmarginal vein very short, nearly absent. Stigmal vein almost forming a right angle with marginal vein. Hind tibia $1.1 \times$ as long as hind coxa. Metabasitarsus (MtT1) 3 times as long as MtT2.

Metasoma. With 6 apparent tergites; tergites 3 to 6 each showing a row of elongated setae. Ovipositor sheaths inconspicuous, not protruding from the metasoma. 


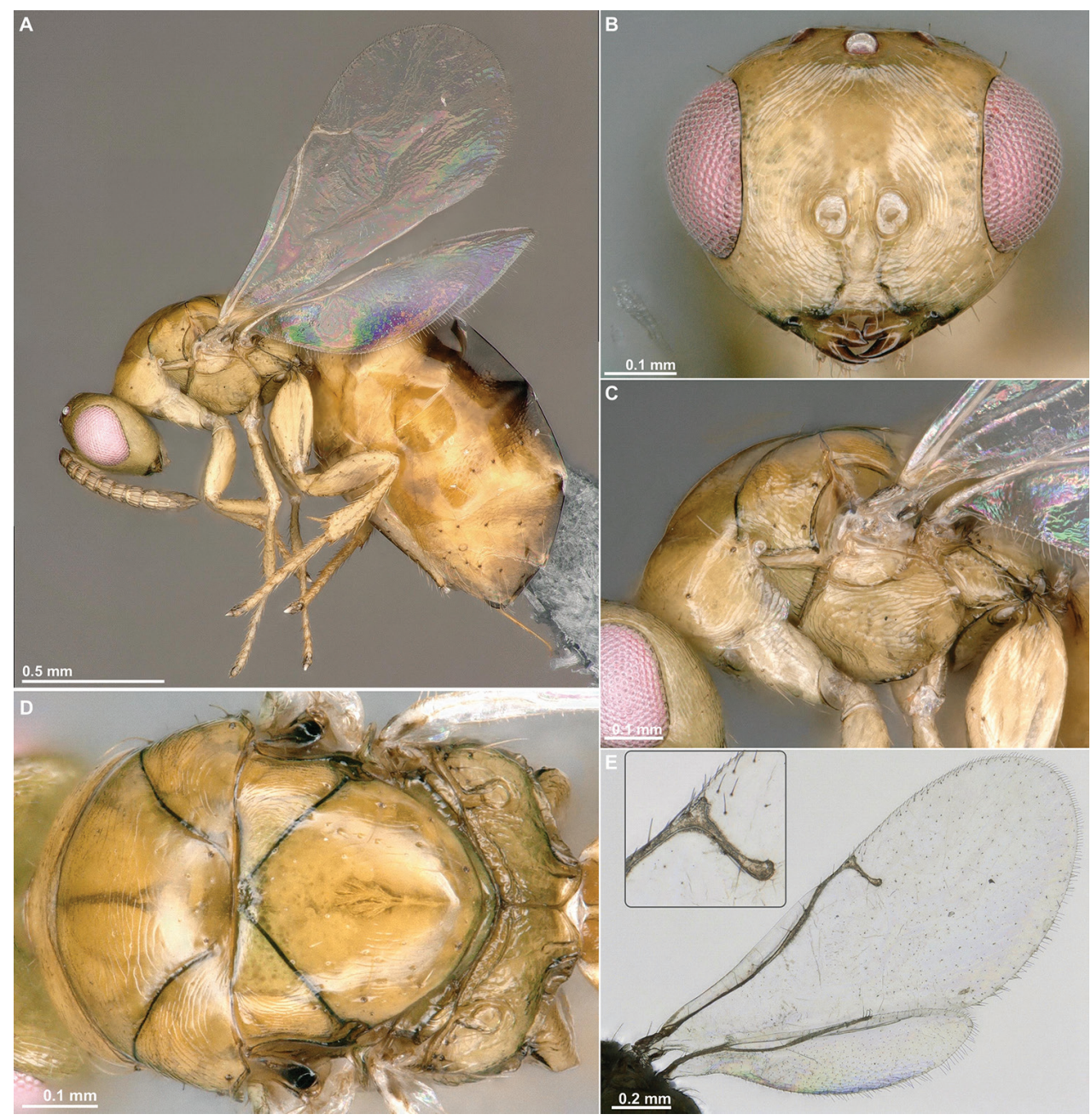

Figure 4. Sycobia hodites Farache \& Rasplus, sp. n. Female. A Habitus, lateral view B Head, frontal view C Mesosoma, lateral view D Mesosoma, dorsal view E Wings and detail of venation.

Ovipositor teeth of homogeneous height; ovipositor with scale-like projections located just before the ovipositor teeth.

Measurements $(\mu \mathrm{m})$. Posterior ocellar distance 133; ocellocular distance 88; lateral ocellar line 67. Antennomeres length): scape 159; pedicel 63; anellus 10; F(unicle) 1 52; F2 48; F3 54; F4 52; F5 53; F6 55; clava 146. Forecoxa length 233; forefemur 303; foretibia 303; foretarsomere (FoT): FoT1 75; FoT2 39; FoT3 40; FoT4 22; FoT5 43. Metacoxa length 366; metafemur 384; metatibia 412; metatarsomeres (MtT): MtT1 208; MtT2 63; MtT3 50; MtT4 34; MtT5 52.

Winged male (Fig. 6). Mostly similar to female. Body length $2 \mathrm{~mm}$. Body color mostly pale yellow. Head. Mandibles and oral margin brown. Metasoma dorsally brown. Head square to transverse, $1.1 \times$ as wide as high. Toruli contiguous. Mandibles 


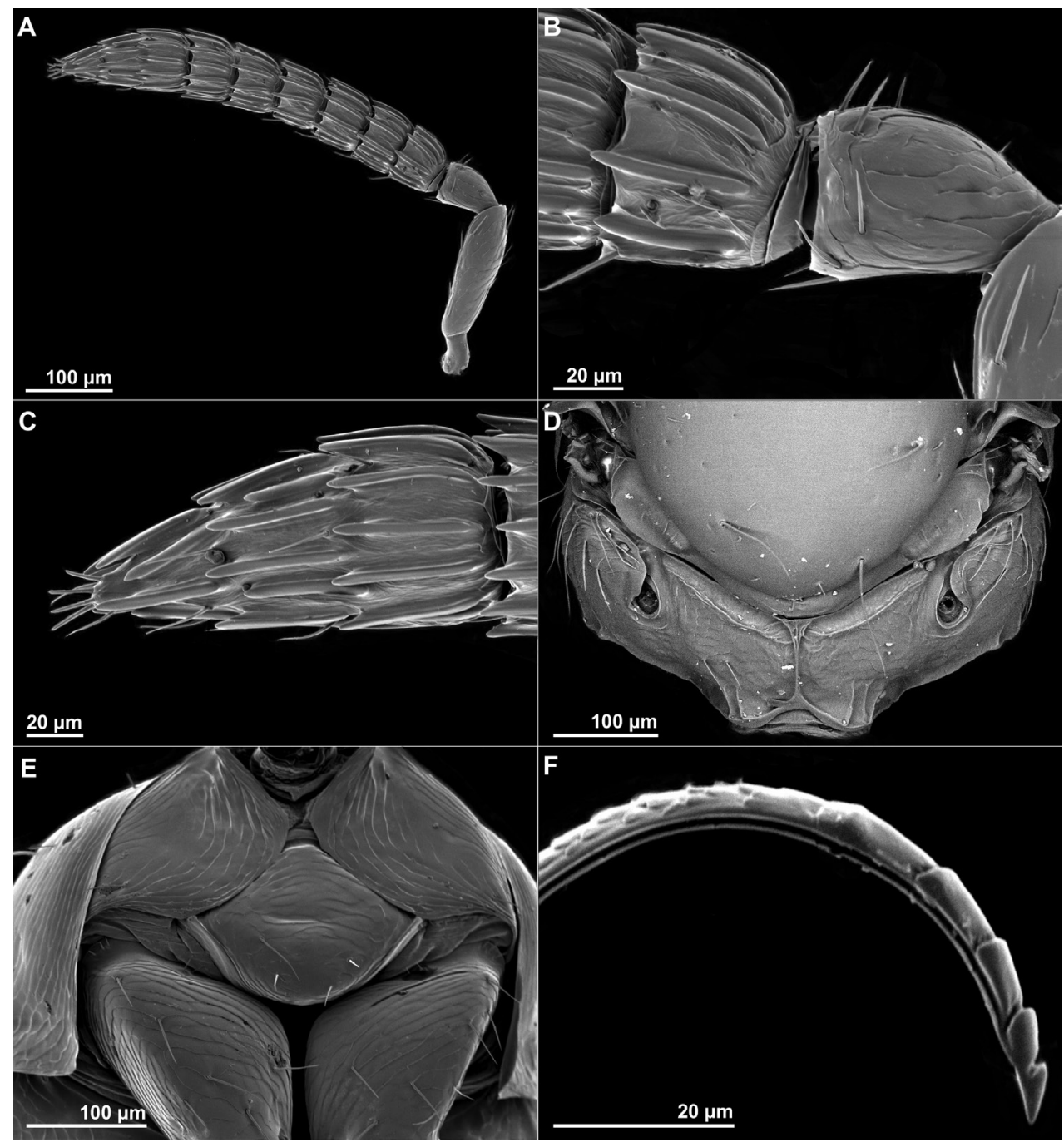

Figure 5. Sycobia hodites Farache \& Rasplus, sp. n. Female, sem. A Antenna B Close-up of the pedicel, anellus and f1 C Clava D Propodeum in dorsal view E Prosternum F Ovipositor.

elongated, larger than in females. Distance from torulus to oral margin $0.6 \times$ distance from torulus to median ocellus. Ocelli well developed. POL 1.0-1.1× OOL. Funicular segments transverse, less than $0.5 \times$ as long as wide. Pronotum elongated, nearly $0.5 \times$ as long as wide in dorsal view. Propodeum without a median longitudinal crest or furrows. Wings slightly infuscate.

Brachypterous male (Fig. 7). Showing two more or less discrete forms. Body length $1.5 \mathrm{~mm}$ (pale form) to $2.0 \mathrm{~mm}$ (yellow-orange form). Body color from pale yellow to yellow orange. Mesothorax slightly green. Head nearly square. Eyes and ocelli reduced compared to winged forms. Toruli contiguous. POL 0.6-1.0× OOL. 


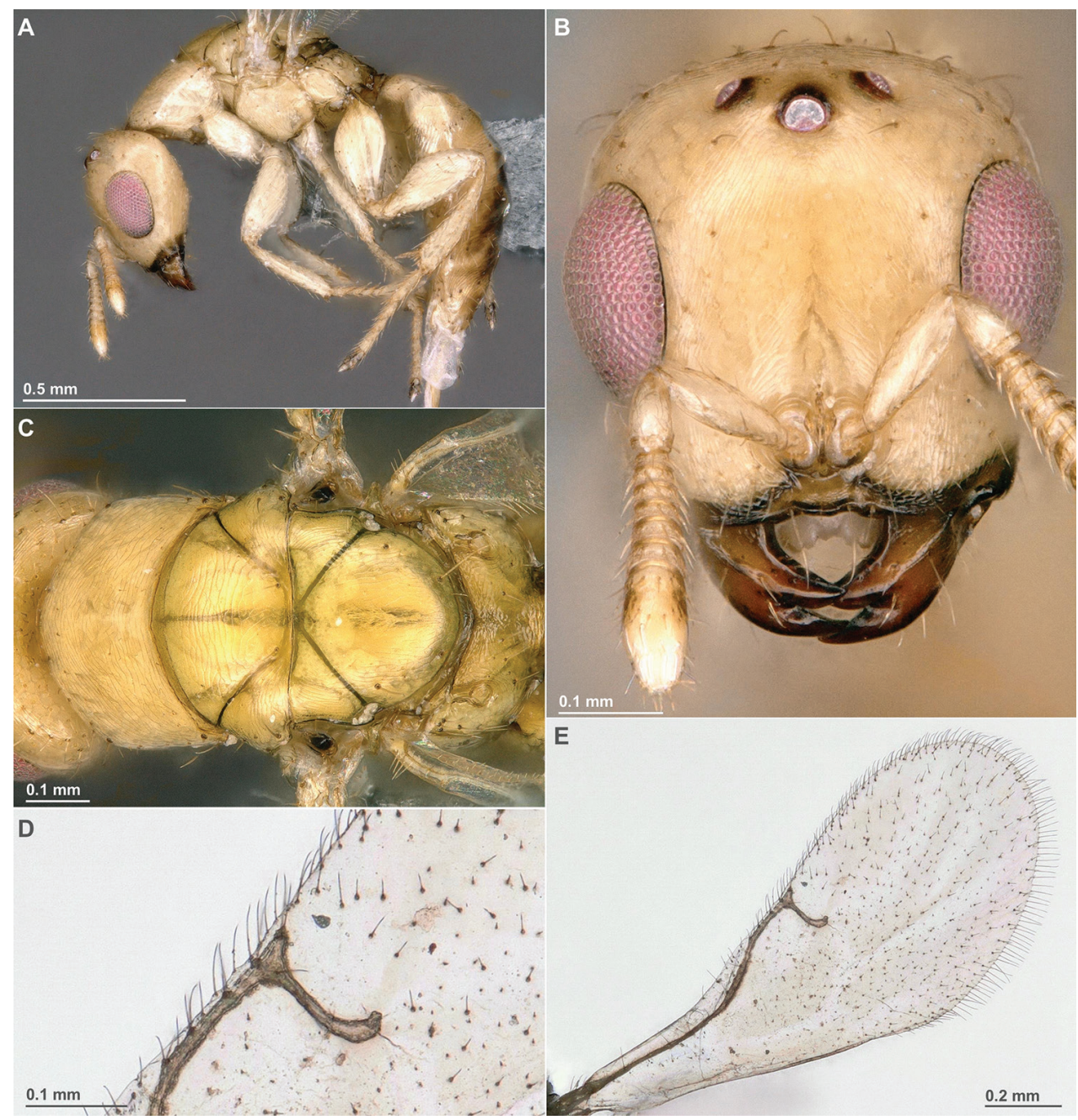

Figure 6. Sycobia hodites Farache \& Rasplus, sp. n. Winged male. A Habitus, lateral view B Head, frontal view C Mesosoma, dorsal view D Detail of wing venation E Forewing.

Mandibles and oral margin brown. Funicular segments transverse, less than $0.5 \times$ as long as wide. Pronotum elongated, nearly $0.6-0.7 \times$ as long as wide in dorsal view. Notauli incomplete. Propodeum without a median longitudinal crest or furrows, sometimes highly setose.

Comparative comments. Sycobia hodites Farache \& Rasplus sp. n. differs from other congeneric species by the following characters. Females: (1) antennae inserted above the level of the ventral margins of the compound eyes and below the median region of compound eyes - inserted at the level of the ventral margins of the compound eyes in S. mathewi; (2) anelli transverse and inconspicuous in females - nearly square in $S$. mathewi; (3) anterior portion of propodeum with two 


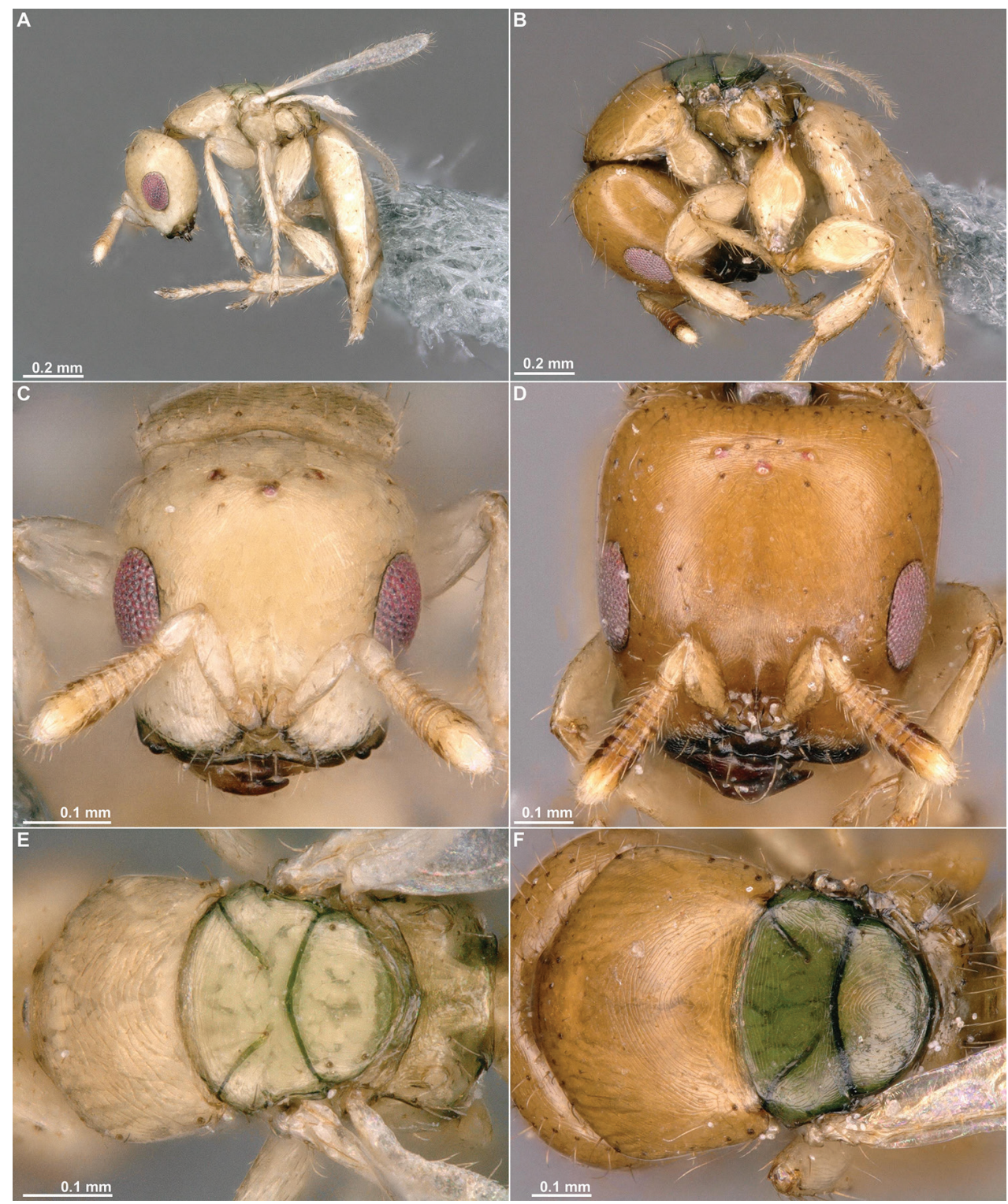

Figure 7. Sycobia hodites Farache \& Rasplus, sp. n. Brachypterous males. A, C, E Small form B, D, F Large form A, B Habitus, lateral view C, D Head, frontal view E, F Mesosoma, dorsal view.

broad furrows, parallel to the anterior margin of propodeum - furrows absent in S. bethyloides and S. mathewi. Males: (4) mandibles short, not protruding from the head - mandibles long and scythe-like in S. bethyloides (5) funicular segments transverse, funicle near as long as scape - funicle segments nearly square (6) pronotum shorter than wide in dorsal view - much longer than wide in S. bethyloides and S. mathewi; (7) petiole short, inconspicuous - longer than wide and conspicuous in $S$. bethyloides and S. mathewi. 


\section{Discussion}

Ficus benjamina is widely cultivated around the world as an ornamental plant, yet few cases of fig wasp colonists (i.e., wasps associated with other local fig trees) are known for this species. There is a single record where a Pegoscapus species, native to the Neotropics, was registered associated with F. benjamina introduced in Costa Rica (Ramírez and Montero 1988). Cases of fig wasp followers for this Ficus species have never been reported. This contrasts with $F$. microcarpa, which also belongs to section Conosycea and is widely introduced over the world. This species exhibits a diverse community of fig wasp followers and colonists (Wang et al. 2015a). The community of wasps associated with fig inflorescences is highly diverse and often poorly known (Bouček 1988), even for widely introduced species, which imposes difficulties in tracing biological invasions. Indeed we can only infer the probable origin of Sycobia hodites, which is probably native to Asia or Australasia (Darwell et al. 2018).

Sycobia hodites belongs to the guild of large gall inducers (Darwell et al. 2018), however its ovipositor structure is not consistent with other large sized species that induce galls in the fig receptacle (e.g., Anidarnes, Idarnes group incertus, Conidarnes and Pseudidarnes, Elias et al. 2018), which lack teeth on their ovipositors. Conversely the ovipositor of $S$. hodites bears homogeneously-sized terminal teeth, compatible with the ovipositor structure of species that induce galls in the ovaries of pistillate flowers (e.g., Idarnes group flavicollis and some Sycophaga species (Elias et al. 2018)). Indeed, the gall of $S$. hodites keeps the remains of the floral stigma (Fig. 2B), showing that it developed from a differentiated pistillate flower. This finding highlights that one guild (i.e., large gall inducers) can in fact encompass different oviposition strategies. This is important for understanding the ecological interactions among fig trees and their associated wasps, as gallers that use receptacle tissues, and those that use flower ovaries have a distinct impact on fig tree reproduction, and consequently on the fig-fig wasp mutualism.

Sycobia hodites is one of the very few species of Epichrysomallinae known to have polymorphic males (Joseph 1961; Vincent and Compton 1992) and represents the first record of brachypterous males for the genus Sycobia. In fig wasps, sexual selection on male mating opportunities favored winged males in species with small broods and wingless males in species with large broods (Cook et al. 1997; Cruaud et al. 2011). The large brood size observed in some of our $S$. hodites samplings corroborated this hypothesis and may explain the high proportion of brachypterous males observed. Further investigation is nevertheless needed to confirm this hypothesis, and $S$. hodites appears an ideal model to test it.

Sycobia hodites has not been recorded in recent samplings of fig wasps from native Neotropical figs in Brazil (Farache, unpublished data). In fact, large gall inducers are relatively specific to their hosts (Farache et al. 2018) and therefore cross-occurrence between wasp species in different fig sections may be unlikely. The -140 Ficus species native to the Neotropical region belong to sections Americanae and Pharmacosycea, whereas Ficus benjamina belongs to section Conosycea, native to Asia, Australasia and Madagascar (Berg 1989). The potential of this invasive wasp species to induce galls in Neotropical fig species should be evaluated experimentally in order to test the potential of interference in native Ficus-associated communities. 
As $S$. hodites is a gall making fig wasp, its presence may contribute to prevent $F$. benjamina becoming invasive if the pollinator of $F$. benjamina, Eupristina koningsbergeri Grandi, 1916, colonizes the Neotropical region in the near future. Indeed, a species of Meselatus Girault, 1922, another epichrysomalline fig wasp associated with F. microcarpa, appears to be an excellent candidate for biocontrol of this invasive fig (Wang et al. 2015b). However, the presence of $S$. hodites opens the opportunity for the establishment of species belonging to other trophic levels such as cleptoparasite and parasitoid wasps, having, therefore, a potential future impact on the community of non-pollinating fig wasps associated with $F$. benjamina.

\section{Conclusions}

Sycobia hodites sp. n. associated with Ficus benjamina is described here. Since neither Epichrysomallinae nor its host are native to the New World, this species can be considered as an invasive species. It is remarkable that this species was described based on specimens collected outside its probable native range, which is an indication of the great need of taxonomic studies in Chalcidoidea. The species is a gall inducer and a competitor that may encumber a future establishment of the pollinator of $F$. benjamina in the New World and prevent its natural reproduction.

\section{Acknowledgements}

We thank EM Soares and LF Silva, for helping sampling F. benjamina in Acre. We thank Rodrigo Ferreira Silva for sputter-coating specimens for SEM. FHAF and RASP were funded by FAPESP (2015/06430-2, 2015/25417-7, 2017/00647-5) and CNPq (306078/2014-7). This study was financed in part by the Coordenação de Aperfeiçoamento de Pessoal de Nível Superior - Brasil (CAPES) - Finance Code 001.

\section{References}

Abràmoff MD, Magalhães PJ, Ram SJ (2004) Image Processing with ImageJ. Biophotonics International 11:36-42.

Baquero OS (2017) ggsn: North Symbols and Scale Bars for Maps Created with 'ggplot2' or 'ggmap'. R package version 0.4.0. https://CRAN.R-project.org/package=ggsn

Beardsley JW (1998) Chalcid wasps (Hymenoptera: Chalcidoidea) associated with fruit of Ficus microcarpa in Hawaii. Proceedings of the Hawaiian Entomological Society 33: 19-33.

Beardsley JW, Rasplus J-Y (2001) A new species of Josephiella (Hymenoptera: Agaonidae) forming leaf galls on Ficus microcarpa L. (Moraceae). Journal of Natural History 35: 33-40. https://doi.org/10.1080/002229301447871

Berg CC (1989) Classification and distribution of Ficus. Experientia (Basel) 45: 605-611. https://doi.org/10.1007/BF01975677 
Bouček Z (1988) Australasian Chalcidoidea (Hymenoptera). A biosystematic revision of genera of fourteen families, with a reclassification of species. C.A.B. International, Wallingford, $832 \mathrm{pp}$.

Cook JM, Compton SG, Herre EA, West SA (1997) Alternative mating tactics and extreme male dimorphism in fig wasps. Proceedings of the Royal Society of London Series B Biological Sciences 264: 747-754. https://doi.org/10.1098/rspb.1997.0106

Cruaud A, Jabbour-Zahab R, Genson G, Kjellberg F, Kobmoo N, van Noort S, Yang D-R, Peng Y-Q, Ubaidillah R, Hanson PE, Santos-Mattos O, Farache FHA, Pereira RAS, Kerdelhue C, Rasplus J-Y (2011) Phylogeny and evolution of life-history strategies in the Sycophaginae non-pollinating fig wasps (Hymenoptera, Chalcidoidea). BMC Evolutionary Biology 11: 178. https://doi.org/10.1186/1471-2148-11-178

Dalman JW (1820) Försök till Uppställning af Insect-familjen Pteromalini, i synnerhet med afseen de på de i Sverige funne Arter. Kungliga Svenska Vetenskapsakademiens Handlingar 41: $123-173$

Darwell CT, Segar ST, Cook JM (2018) Conserved community structure and simultaneous divergence events in the fig wasps associated with Ficus benjamina in Australia and China. BMC Ecology 18: 13. https://doi.org/10.1186/s12898-018-0167-y

Dehgan B (1998) Landscape plants for subtropical climates. University Press of Florida, Gainesville, FL, 656 pp.

Elias LG, Kjellberg F, Farache FHA, Almeida EAB, Rasplus J-Y, Cruaud A, Peng Y-Q, Yang D-R, Pereira RAS (2018) Ovipositor morphology correlates with life history evolution in agaonid fig wasps. Acta Oecologica 90: 109-116.https://doi.org/10.1016/j.actao.2017.10.007

Farache FHA, Cruaud A, Rasplus J-Y, Cerezini MT, Rattis LM, Kjellberg F, Pereira RAS (2018) Insights into the structure of plant-insect communities: specialism and generalism in a regional set of non-pollinating fig wasp communities. Acta Oecologica 90: 49-59. https:// doi.org/10.1016/j.actao.2018.02.006

Farache FHA, do Ó VT, Pereira RAS (2009) New occurrence of non-pollinating fig wasps (Hymenoptera: Chalcidoidea) in Ficus microcarpa in Brazil. Neotropical Entomology 38: 683-685. https://doi.org/10.1590/S1519-566X2009000500020

Feng G, Huang D-W (2010) Description of a new species of Odontofroggatia (Chalcidoidea, Epichrysomallinae) associated with Ficus microcarpa (Moraceae) with a key to species of the genus. Zootaxa: 40-48. https://doi.org/10.11646/zootaxa.2335.1.4

Ferrière C (1929) Chalcidiens gallicoles de Java. Annales de la Société Entomologique de France 98: 143-161.

Figueiredo RA, Motta-Júnior JC (1986) Análise da relação entre Ficus microcarpa (Moraceae) e um microhimenóptero hospedeiro na região de São Carlos, SP. Anais do Congresso da Sociedade Botânica de São Paulo 6: 103-107.

Figueiredo RA, Motta-Júnior JC (1993) Biology of Walkerella yashiroi (Ishii) (Hymenoptera, Chalcidoidea). Naturalia (Rio Claro) 18: 27-32.

Figueiredo RA, Motta-Júnior JC, Vasconcellos LAS (1995) Pollination, seed dispersal, seed germination and establishment of seedlings of Ficus microcarpa, Moraceae, in southeastern Brazil. Revista Brasileira de Biologia 55: 233-239.

Galil J, Copland JW (1981) Odontofroggatia galili Wiebes in Israel, a primary fig wasp of Ficus microcarpa L. with a unique ovipositor mechanism (Epichrysomallinae, Chalcidoidea). 
Proceedings of the Koninklijke Nederlandse Akademie Van Wetenschappen Series C-Biological and Medical Sciences 84: 183-195.

Girault AA (1922) New chalcid flies from eastern Australia. III. (Hymenoptera). Insecutor Inscitiae Menstruus 10: 148-154.

Grandi G (1916) Contributo alla conoscenza degli Agaonini (Hymenoptera, Chalcididae) di Ceylon e dell'India. Bollettino del Laboratorio di Zoologia Generale e Agraria della R Scuola Superiore d'Agricoltura, Portici 11: 181-234.

Grandi G (1923) Imenotteri dei fchi dell fauna olartica e indo-malese. Annali del Museo Civico di Storia Naturale di Genova 51: 101-108.

Hill DS (1967) Figs (Ficus spp.) and fig-wasps (Chalcidoidea). Journal of Natural History 1: 413-434. https://doi.org/10.1080/00222936700770401

Ibarra-Manríquez G, Cornejo-Tenorio G, González-Castañeda N, Piedra-Malagón EM, Luna A (2012) El género Ficus L. (Moraceae) en México. Botanical Sciences 90: 389-452. https://doi.org/10.17129/botsci.472

Ishii T (1934) Fig Chalcidoids of Japan. Kontyu Tokyo 8: 84-100.

Joseph KJ (1956) Contributions to our knowledge of fig insects (Chalcidoidea: parasitic Hymenoptera) from India. VII. Descriptions of fifteen new and revision of some old species. Annales de la Société Entomologique de France 125: 97-133.

Joseph KJ (1961) Contributions to our knowledge of fig insects from India VIII. Notes on some new fig insects. Journal of Karnataka University 4: 88-100.

Jousselin E, Rasplus J-Y, Kjellberg F (2001) Shift to mutualism in parasitic lineages of the fig/fig wasp interaction. Oikos 94: 287-294. https://doi.org/10.1034/j.1600-0706.2001.940209.x

Kjellberg F, Jousselin E, Hossaert-McKey M, Rasplus J-Y (2005) Biology, ecology, and evolution of fig-pollinating wasps (Chalcidoidea, Agaonidae). In: Raman A, Schaefer CW, Withers TM (Eds) Biology, ecology and evolution of gall-inducing arthropods: volume 2. Science Publishers, Inc., New Hampshire, 539-572.

Mack RN, Simberloff D, Lonsdale WM, Evans H, Clout M, Bazzaz FA (2000) Biotic invasions: Causes, epidemiology, global consequences, and control. Ecological Applications 10: 689-710. https://doi.org/10.2307/2641039

Mayr G (1906) Neue Feigen-Insekten. Entomologische Zeitung Wien 25: 153-187.

Niu L-M, Hu H-Y, Huang D-W, Fu Y-G, Peng ZQ (2009) Brood size: a major factor influencing male dimorphism in the non-pollinating fig wasp Sycobia sp. Ecological Entomology 34: 696-701. https://doi.org/10.1111/j.1365-2311.2009.01123.x

Noyes JS (1982) Collecting and preserving chalcid wasps (Hymenoptera: Chalcidoidea). Journal of Natural History 16: 315-334. https://doi.org/10.1080/00222938200770261

R Core Team (2018) R: A language and environment for statistical computing. R Foundation for Statistical Computing, Vienna, Austria.

Ramírez W, Montero J (1988) Ficus microcarpa L., F. benjamina L. and other species introduced in the New World, their pollinators (Agaonidae) and other fig wasps. Revista de Biología Tropical 36: 441-446.

Rasplus J-Y, Harry M, Perrin H, Chassagnard M-T, Lachaise D (2003) Les Ficus (Moraceae) et l'entomofaune des figues (Hym. Agaonidae, Pteromalidae, Torymidae, Eurytomidae; Dipt. Drosophilidae; Col. Curculionidae) du mont Nimba en Guinée, 107-182. 
Rasplus J-Y, Soldati L (2005) Familia Agaonidae. In: Fernández F, Sharkey MJ (Eds) Introdución a los Hymenoptera de la Región Neotropical. Sociedad Colombiana de Entomología \& Universidad Nacional de Colombia, Bogotá, 683-698.

Richardson DM, Allsopp N, D’Antonio CM, Milton SJ, Rejmanek M (2000) Plant invasions - the role of mutualisms. Biological Reviews 75: 65-93. https://doi.org/10.1017/ S0006323199005435

Simberloff D, Martin JL, Genovesi P, Maris V, Wardle DA, Aronson J, Courchamp F, Galil B, Garcia-Berthou E, Pascal M, Pysek P, Sousa R, Tabacchi E, Vila M (2013) Impacts of biological invasions: what's what and the way forward. Trends in Ecology \& Evolution 28: 58-66. https://doi.org/10.1016/j.tree.2012.07.013

South A (2017) rnaturalearth: World map data from Natural Earth. R package version 0.1.0. https:/CRAN.R-project.org/package=rnaturalearth

van Noort S, Rasplus J-Y (2018) figweb. http://www.figweb.org [accessed August 18.2018]

van Noort S, Wang R, Compton SG (2013) Fig wasps (Hymenoptera: Chalcidoidea: Agaonidae, Pteromalidae) associated with Asian fig trees (Ficus, Moraceae) in southern Africa: Asian followers and African colonists. African Invertebrates 54: 381-400. https://doi. org/10.5733/afin.054.0208

Vianna-Filho MDM, Alves RJV, Peng YQ, Pereira RAS (2017) Naturalization of the Bodhi fig tree (Ficus religiosa L. - Moraceae) in Brazil. Bioscience Journal 33: 177-182. https://doi. org/10.14393/BJ-v33n1a2017-34177

Vincent SL, Compton SG (1992) A new polymorphic species of fig wasp from Ficus ingens (Moraceae). Journal of African Zoology 106: 363-370.

Vitousek PM, D’Antonio CM, Loope LL, Rejmanek M, Westbrooks R (1997) Introduced species: A significant component of human-caused global change. New Zealand Journal of Ecology 21: 1-16.

Walker F (1871) Notes on Chalcidiae Part IV. Chalcididae, Leucospidae, Agaonidae, Perilampidae, Ormyridae, Encyrtidae. E.W. Janson, London, 55-70.

Wang R, Aylwin R, Barwell L, Chen XY, Chen Y, Chou LS, Cobb J, Collette D, Craine L, Giblin-Davis RM, Ghana S, Harper M, Harrison RD, McPherson JR, Peng YQ, Pereira RAS, Reyes-Betancort A, Rodriguez LJV, Strange E, van Noort S, Yang HW, Yu H, Compton SG (2015a) The fig wasp followers and colonists of a widely introduced fig tree, Ficus microcarpa. Insect Conservation and Diversity 8: 322-336. https://doi. org/10.1111/icad.12111

Wang R, Aylwin R, Cobb J, Craine L, Ghana S, Reyes-Betancort JA, Quinnell RJ, Compton SG (2015b) The impact of fig wasps (Chalcidoidea), new to the Mediterranean, on reproduction of an invasive fig tree Ficus microcarpa (Moraceae) and their potential for its biological control. Biological Control 81: 21-30.

Wickham H (2009) ggplot2: elegant graphics for data analysis. Springer-Verlag, New York, 212 pp. 


\section{Supplementary material I}

\section{Occurrence of Sycobia hodites in studied localities}

Authors: Fernando Henrique Antoniolli Farache, Cecilia Bernardo Pereira, Cristiana Koschnitzke, Levi Oliveira Barros, Elmecelli Moraes de Castro Souza, Daniel Tirapeli Felício, Fabián Gatti, William Cardona, Jean-Yves Rasplus, Rodrigo Augusto Santinelo Pereira

Data type: occurrences

Copyright notice: This dataset is made available under the Open Database License (http://opendatacommons.org/licenses/odbl/1.0/). The Open Database License $(\mathrm{ODbL})$ is a license agreement intended to allow users to freely share, modify, and use this Dataset while maintaining this same freedom for others, provided that the original source and author(s) are credited.

Link: https://doi.org/10.3897/jhr.67.29733.suppl1 